\title{
The Broad Value of a PhD in Political Science
}

\author{
Michael H. Murakami, Google Team
}

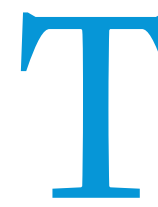

oday I am a researcher at Google and one of a handful of employees, out of a global workforce of more than 30,000 , the with a $\mathrm{PhD}$ in political science. But less than two years ago, I was a tenure track professor of political science at a research university and could barely have imagined the unusual path my professional life would take. That path has been incredibly rewarding, as well as instructive both of the broad value a $\mathrm{PhD}$ in political science (and the social sciences more generally) and of the growing role for quantitative research outside of the academy. I recount much of that path below, with the hope that it might prove useful for those graduate students, post-docs, and professors who might be inclined to apply the knowledge and skills they have acquired in unconventional professional paths of their own.

Of course, leaving academia was not something I decided to do on a whim. It was the result of careful and prolonged thought about what I needed to be fulfilled in my professional life. I felt indebted and grateful for all of the thought, time, and support so many teachers, mentors, and colleagues had lended so I could have a successful academic career. And the decision was fraught with the concern that a transition out of the academy would be painful. It might mean starting over at the bottom of the responsibility and compensation ladder. The work might not be as interesting, stimulating, or as varied as the teaching, presenting, research, analyzing, and writing incumbent upon full-time professors. And I would be giving up the benefits of academia, possibly irreversibly, for a life with no prospect of tenure. So I embarked on the idea of exploring other career opportunities carefully.

\section{THE JOBS LANDSCAPE}

The future career paths I considered were, of course, greatly influenced by my particular areas of expertise. I started by using a simple strategy: take a comprehensive inventory of my knowledge and skills, enumerate specific career paths that I could begin given those skills, rank those paths on a number of desirable (and undesirable) qualities, and start testing the waters for the top choices by looking for openings and applying for positions.

First, I took inventory of all the qualities I had to offer prospective employers, striving to be as comprehensive as possible and not to censor any at this early stage, even if some qualities seemed inconsequential or unimportant. I had obvious expertise in the subjects of my academic research focus: American politics, political psychology, Congress, public opinion, race and ethnic politics,

Michael H. Murakami received his $\mathrm{PhD}$ in political science from University of California, Berkeley in 2008. Since then he has been an APSA Congressional Fellow, a postdoctoral associate at Yale University's Center for the Study of American Politics, and an assistant professor at the University of Illinois at Chicago. He is now a Quantitative Marketing Manager at Google, based in Mountain View, California. He can be reached at mikemurakami@google.com. and political participation. I had also spent a year working on Capitol Hill as an APSA Congressional Fellow, which had given me some limited policy experience on the issues of education, social security, pensions, and labor. A number of careers where this expertise gave me a leg up: I could work for a pollster, for campaigns, on the Hill (either for a member of Congress or for a legislative committee), for any number of political actors who try to shape the legislative process (although lobbying seemed less likely to fit a researcher's skill set), or at agencies that supervised electoral processes (registration, elections, turnout initiatives). I could even try working at the Department of Education, given my time on the subject as a legislative fellow, my experience in higher education, and my passion for education reform.

These options were the ones rooted in what I felt was my domain expertise. But at the time the list seemed limiting, and I didn't want to prematurely consider any possibility out of range. The real world of politics is fast paced and stimulating but generally underpaid and not necessarily one in which careful research design and full appreciation of the difficulty of making causal inferences (and therefore, my graduate education) would be fully appreciated. The more I thought about it, the more I realized that perhaps the most important expertise I had developed was not my knowledge of American politics, but of research design, project management, and statistical analysis. In fact, I realized that what I loved most about political science was the social science: the hypothesis generation, the thinking of ways to test them, the empirical evaluations, and the rigor of holding inferences to a high standard of skepticism. (The politics was less interesting to me-increasingly so over time.) I found myself wanting to keep asking social science questions and conducting rigorous research to understand why people do what they do and think what they think.

So I began to expand my purview to include a variety of research positions. Think tanks were an obvious choice. So, too, were polling and research firms that engaged in a variety of nonpolitical research projects during the election offseason. There are also a number of research consulting firms, some small boutique shops and others multinational corporations, with a variety of business and government clients. As I investigated open job positions, I noticed a high demand for sampling statisticians, survey researchers, statistical analysts, even "social scientists" at private companies, government agencies, and nonprofits. Conducting carefully designed research to understand social behavior was much more widespread outside of academia than I had initially realized.

One particular area piqued my interest: market/marketing research. (Although technically, "market research" is research of the broad marketplace for particular products or services, and "marketing research" is specifically designated for research investigating the effectiveness of marketing campaigns, the two are 
often used interchangeably and are often conducted by the same department-or even individuals-within a business or organization.) Extremely interesting job descriptions were posted for social scientists who could understand how to improve business conditions, increase customer loyalty, discover new sources of revenue, or refocus resources in advantageous ways. These job descriptions, and these empirical questions, seemed new and intriguing to me. I was excited by the thought of testing socialpsychological hypotheses using quantitative methodologies in a new domain, and conducting marketing research quickly rose to the top of my list of desirable career paths. But first I had to get my foot in the door, which might prove tricky. I had to find an opportunity where the research background and technical skills were valued more than a formal background in marketing, of which I only had part-time consulting experience.

I was, however, never much paralyzed by the thought of having to find an opportunity in marketing research that didn't require marketing experience. In retrospect, this was probably because I believed two things would prove true about the labor market I was thinking of entering: (1) that the research skills I had accrued as a graduate student were much rarer and more difficult to acquire than a background in marketing; and (2) that the politics I had studied for several years had much in common with other marketplaces.

\section{THE PREMIUM OF RESEARCH EXPERTISE}

The first proposition seems obvious to me now. The number of marketing majors graduating every year must dwarf the number of $\mathrm{PhDs}$ produced who are interested in marketing research. (As a rough estimate of the order of magnitude, the Department of Education recorded 347,985 business/marketing majors graduated with a Bachelor's degree in 2009, and climbing; while $1,194 \mathrm{PhDs}$ were awarded in business-related fields.) Anecdotally, many marketers in my own social and professional networks didn't appear to have the skillset required for quantitative research design and analysis, nor a particularly strong desire to acquire these skills. More importantly, when combing job descriptions for positions for marketing research, strict requirements tended to include coursework and experience working with statistics, understanding of experimental design, and knowledge of sampling and survey methodology; experience in marketing was sometimes desired, but rarely listed among the chief qualifications.

In particular, it became clear that there was a class of opportunities where a PhD (in a variety of fields) was recommended or required because the job was first and foremost a research position and demanded a solid understanding of designing empirical investigations for making causal inferences. Many companies not only wanted descriptive quantitative research, they wanted research to answer questions about how and why consumers, companies, or other actors behave the way they do, and how to affect those behaviors. They wanted to know the answers to questions like, "did this ad campaign increase our brand awareness?", "does greater customer satisfaction increase the amount they spend?", and "which of our HR campaigns had the largest positive effect on employee retention and productivity?" Because of this, the salient qualifications included knowledge of the value of true randomized experiments, statistical methods for coping with quasi- or nonexperimental design, power analysis, sampling, weighting, and the pitfalls and corrections of measurement. A background in statistics was also highly valued: it was common for a job listing to enumerate specific analytical techniques like multivariate modeling, factor analysis, matching techniques, cluster analysis, and multilevel modeling.

\section{THE NONUNIQUENESS OF THE POLITICAL MARKETPLACE}

The second observation, which both reinforced my belief that I could transition into marketing research and served as an important piece of persuasion as I produced applications materials and interviewed with prospective employers, was that politics isn't all that different from other markets. Policy entrepreneurs, issue advocates, parties, and candidates were selling policy positions, reforms, ideologies, and party labels, in much the same way firms sell goods, services, and brands. And voters are like customers, only they cast votes, volunteer, or donate money rather than make purchases.

Most importantly, the kinds of activities that marketers engage in to increase sales, drive loyalty, build brands, and reach new customers are the same ones that candidates and parties engage in to enlist support: they try to understand their potential customers and the way they think. They seek to grab their attention, inform them, persuade them, and convert them with campaigns consisting of carefully tested messages, paid advertising across multiple platforms, and social media.

There are, of course, some extremely important ways in which the electoral marketplace is unique. But emphasizing the similarities first allowed me to believe I could transition with my current knowledge and background, and second, allowed me to sell myself to others. Finally, recognizing and speaking about how various markets are different from political markets in interviews demonstrated high-level theoretical understanding of economic systems and analytical sense, two key attributes employers are looking for in market researchers.

\section{SUCCESSFULLY NAVIGATING THE JOB SEARCH WATERS}

A few characteristics certainly helped me navigate the difficult swim from the halls of academia to the boardroom. First, the hunch that I have knowledge and skills that would be of value to a variety of companies and nonprofits became a steadfast belief that kept me motivated and my eyes on the prize. When a screener interview did not go well or an opportunity closed, I never believed this meant I would not find a good match. It might take time, and it might take more time than I initially expected (especially considering the state of the economy), but I was confident that I could add real value outside of teaching and publishing. Whether this confidence was well founded or not, it gave me a thick skin.

Second, my willingness to move to other areas of the country opened up many opportunities that would not have been available otherwise. I had lived in Washington, DC for many years before (first as a grad student researching my dissertation, then as an APSA Congressional Fellow working in the US Senate, and finally as a visiting assistant professor at Georgetown University's department of government), and knew from experience that a $\mathrm{PhD}$ in political science had cache there. Many of my comparativist friends who are experts on certain regions and languages of the world had landed jobs at the State Department, the World Bank, and the Pentagon. Others who studied American politics worked on the Hill, on campaigns, for various issue causes, for pollsters, for think tanks, or as journalists. Of course, a wider net will catch more fish, and so a willingness to relocate increases one's 
employment prospects is a rather general rule. But because the domain expertise of political science is primarily, well, in politics, this rule especially applies to political scientists willing to live in places where such expertise is currency.

Third, cultivating a network of contacts across a variety of fields was crucial for opening doors. Conversations with friends who are project managers, IT professionals, HR specialists, lawyers, marketers, and executives pointed me toward paths I might not have otherwise discovered or considered. They also helped me expand my business vocabulary, increase my conversational purview, and prepare for job interviews. Most of all, they helped me discover that many interesting, rewarding jobs are out there, and that most of them did not require a skill set outside of my comfort zone.

Fourth, I cannot understate the importance of knowledge about research methodology and fluency in quantitative statistical methods, at least for my own particular journey and destination. Technology is making massive amounts of data collection easier, and with the growth of data is an increasing need for analysts who are comfortable designing quantitative research projects, collecting data, and analyzing the results. This is most obvious with Internet technology companies, but also applies to retailers, consumer goods, advertising, hospitality, entertainment, and finance, just to name a few. Businesses everywhere are increasingly making key decisions based on the results of quantitative analysis (and qualitative research), not just intuition and anecdote.

Lastly, I think my biggest asset was a sense of adventure. In a modern labor market in which domain expertise, knowledge of research methodology, and fluency in statistics are of increasing value, more and more researchers are carving novel paths that crisscross or combine careers in academia, business, nonprofit, and government. I welcomed the chance, and the challenge, of applying my research background to a whole different set of empirical questions, methodologies, available data, and audiences.

Currently, my job has many of the "perks" of academia. As part of a research unit, I have many opportunities to collaborate with statisticians, economists, and survey researchers to answer complicated, nonroutine research questions in a timely fashion. Many of the colleagues on my team have a $\mathrm{PhD}$ in statistics, a handful (like me) are one-time professors, and a few are current professors who work with Google as consultants.

My tasks are varied and interesting. There are regular opportunities to write, present, and consume various academic literatures. And I have had many opportunities to communicate the conclusions of my research to influential decision-makers. Google as a company values data-driven decision making, and my research is expected to affect the way we do business-a charge I find both challenging and rewarding.

There are times when I miss thinking about elections, partisanship, and motivated reasoning, but I am also continually excited to apply what I've learned to a variety of questions about human behavior. A strength of political science is that it provides so many of its practitioners with skills that can be so broadly and practically applied. 